\title{
PENGEMBANGAN MODEL PEMBELAJARAN TEMATIK INTEGRATIF EKSTERNAL DAN INTERNAL DI MADRASAH IBTIDAIYAH
}

\author{
Fatchurrohman \\ Institut Agama Islam Negeri (IAIN) Salatiga \\ artur.neno@yaboo.co.id
}

\begin{abstract}
The purpose of this study was to determine the learning theme thematic integrative network of external (religion and general subject) at Islamic elementary schools, the thematic learning network in integrative and internal manner (fiqh, tarih, aqeedah, akhlaq and qur'an hadith), the effectiveness of thematic integrative learning internally and externally at Islamic elementary schools by using a scientific approach. The study used a qualitative approach to the type of Research and Development ( $R$ \& D) by following the model developed by Dick and Lau Cerey. The results showed that the spread of KD in sub-subjects of Islamic Education in Islamic elementary schools cannot be fitting in any theme of learning that has been prepared by the Ministry of Education. Drafting an integrative internal theme network is difficult because each sub-subject PAI has different bierarchy scientific discussion with other sub-subject PAI. After limited trial, Kn and An (fourth classroom teacher MI Mangunsari Salatiga) stated that she is comfortable and suitable teaching with that method.
\end{abstract}

Keywords: Thematic Integrative Internal, External, Madrasah

\begin{abstract}
Abstrak
Tujuan penelitian ini adalab mengetahui jaringan tema pembelajaran tematik integratif eksternal (mapel agama dan umum) di Madrasah Ibtidaiyah, jaringan temapembelajaran tematik integratif internal (Fiqh, Tarih, Aqidah, Akblaq dan al Qur'an Hadits), efektivitas pembelajaran tematik integratif internal dan eksternal di Madrasab Ibtidaiyah dengan menggunakan pendekatan saintifik. Kajian ini menggunakan pendekatan kualitatif jenis Research and Development (RED) dengan mengikuti model yang dikembangkan oleh Dick \& Lau Cerey. Hasil penelitian menunjukkan bahwa penyebaran KD pada sub-sub mata pelajaran Pendidikan Agama Islam di Madrasah Ibtidaiyah tidak dapat masuk pada setiap tema pembelajaran yang telah disusun oleh Kementerian Pendidikan Nasional. Penyusunan jaringan tema integratif internal masih sulit dilakukan karena masing-masing sub mapel PAI memiliki hirarki pembahasan keilmuan yang berbeda dengan sub mapel PAI lainnya. Setelah dilakukan uji coba terbatas, Kn dan An (guru kelas IV MI Mangunsari Kota Salatiga) menyatakan babwa dia merasa nyaman dan cocok mengajar dengan model tersebut.
\end{abstract}

Kata Kunci : Tematik Integratif Internal, Eksternal, Madrasah

Permalink/DOI:http://dx.doi.org/10.18326/infsl3.v9i2.329-350 


\section{Pendahuluan}

Sejalan dengan perubahan Kurikulum Pendidikan Nasional tahun 2013, membawa konskwensi berbagai perubahan dalam dunia pendidikan di Indonesia, khususnya dalam pembelajaran di kelas. Kurikulum 2013 ini menekankan scientific approach dalam pembelajaran dan dikembangkannya model pembelajaran tematik integratif untuk pendidikan tingkat dasar.

Dalam lampiran IV Permendikbud Nomor 81A tahun 2013 ditegaskan bahwa pembelajaran di sekolah tingkat dasar dikembangkan secara tematik, keterpaduan lintas mata pelajaran untuk mengembangkan sikap, keterampilan, dan pengetahuan serta mengapresiasi keragaman budaya lokal.

Kalau dikontekskan pada Madrasah Ibtidaiyah, maka sebenarnya model pembelajaran tematik integratif tersebut belum memadai, mengingat struktur kurikulum di Madrasah Ibtidaiyah terdiri dari mata pelajaran umum dan agama secara jumlah sama banyaknya. Pembelajaran tematik integratif yang ada sekarang baru mengintegrasikan matapelajaran-matapelajaran umum saja, sementara mata pelajaran agama berlum termasuk. Di sisi lain, panduan pembelajaran agama yang dikeluarkan oleh Kementerian Pendidikan dan Kebudayaan belum dikembangkan secara tematik namun masih pokok bahasan-pokok bahasan. Jika demikian, maka kebijakan Kementerian Pendidikan dan Kebudayaan tentang pembelajaran tematik integratif di tingkat pendidikan dasar kurang memadai karena hanya mengintegrasikan mata pelajaran umum dengan mata pelajaran umum; padahal di Madrasah Ibtidaiyah ada mata pelajaran umum dan agama. Oleh karenanya untuk mewujudkan pembelajaran tematik integratif di Madrasah Ibtidaiyah perlu dikembangkan pembelajaran tematik internal dan eksternal.

Ada beberapa persoalan yang akan dijawab melalui kajian ini: 1) Bagaimana jaringan tema pembelajarantematik integratif eksternal (mapel agama dan umum) di Madrasah Ibtidaiyah? 2) Bagaimana jaringan tema pembelajaran tematik integratif internal (Fiqh, Tarih, Aqidah, Akhlaq dan al Qur'an Hadits) di Madrasah Ibtidaiyah? 3) Bagaimana efektivitas pembelajaran tematik integratif internal dan eksternal di Madrasah Ibtidaiyah dengan menggunakan pendekatan saintifik? 


\section{Kajian Teori}

\section{Integrasi Interkoneksi}

Integrasi interkoneksi merupakan upaya mempertemukan antara ilmu-ilmu agama (Islam) dan ilmu-ilmu umum (sain-teknologisosial humaniora). Interaksi antara disiplin-disiplin ilmu tersebut akan saling memperkuat satu dan lainnya, sehingga bangunan keilmuan masing-masing akan semakin kokoh (Fandy Saputra, 2013:1). Fenomena alam yang terangkum dalam ilmu umum dapat ditemukan rujukannya di dalam ilmu agama yang bersumber dari al Qur'an, dan berita-berita yang termaktub dalam al Qur'an dapat dijumpai di alam yang dijelaskan dengan science dan humaniora.

Ahmad Watik Pratiknya (1991:105) menjelaskan cara pandang integratif keilmuan dengan bagan berikut.

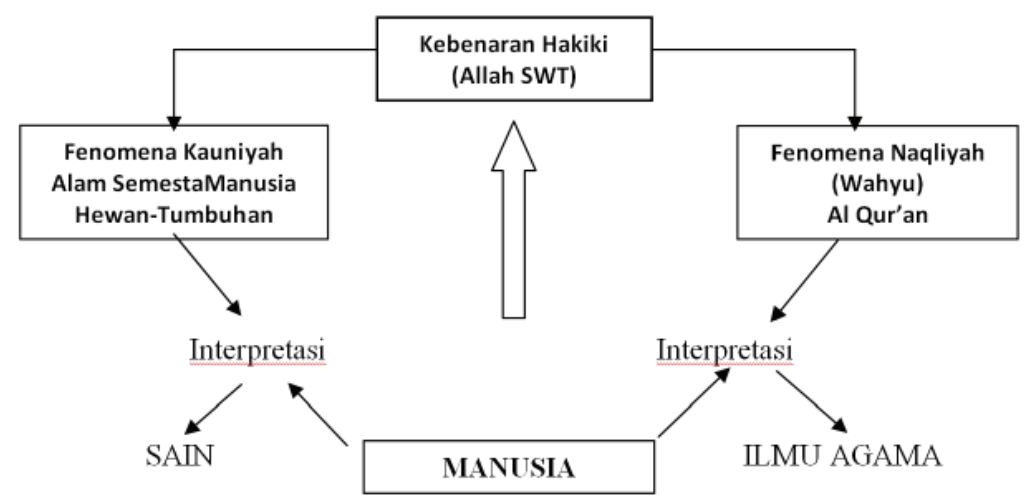

\section{Pembelajaran Tematik Integratif}

a. Pengertian

Pembelajaran tematik integratif adalah pembelajaran yang menggunakan tema untuk mengaitkan beberapa mata pelajaran untuk mengembangkan aspek afektif, kongnitif, dan psikomotorik peserta didik agar dapat memberikan pembelajaran yang bermakna. Istilah tematik digunakan karena pembelajaran tersebut menggunakan tema untuk mengaitkan beberapa mata pelajaran, sedangkan istilah integratif merujuk pada pengembangan seluruh totalitas diri anak yang mencakup aspek afektif, kognitif, dan psikomotorik. 
Ada dua alasan yang mendasari dikembangkannya model pembelajaran tematik integratif, yaitu karakteristik peserta didik dan alasan teoritik. Jean Piaget (Jeanne, 2011:29) mengemukakan empat karakteristik tahap perkembangan kognitif individu, yaitu tahap sensori motorik, praoperasional, operasional konkrit, dan operasional formal. Sedangkan teori yang mendasari pengembangan pembelajaran tematik integratif adalah beberapa teori psikologi belajar, yaitu teori perkembangan Jean Piaget, teori belajar Konstruktivisme, teori belajar Vygotski, teori belajar Bandura, dan teori belajar Bruner (Trianto, 2010:101).

b. Karakteristik dan prinsip dasar

Karakteristik pembelajaran tematik integratif adalah: 1) berpusat pada peserta didik; 2) memberikan pengalaman langsung; 3) tidak terjadi pemisahan mata pelajaran; 4) menyajikan konsep yang terpadu dari berbagai mata pelajaran; 5) bersifat fleksibel; 6) proses pembelajaran mudah disesuaikan dengan minat dan kebutuhan peserta didik; 7) menggunakan prinsip pembelajaran yang aktif, kreatif, efektif, dan menyenangkan.

Sementara itu, dalam mengembangkan pembelajaran tematik integratif di kelas, ada beberapa prinsip dasar yang mesti diperhatikan yaitu: 1) pembelajaran bersifat kontekstual atau terintegrasi dengan lingkungan; 2) bentuk belajar dirancang agar siswa menemukan tema; dan 3) efisiensi (Yuswadiwijaya, 2013:2).

\section{Pendekatan saintifik (scientific approach)}

Pembelajaran dengan pendekatan saintifik merupakan proses pembelajaran yang dirancang sedemikian rupa agar peserta didik secara aktif mampu mengkonstruk konsep, hukum atau prinsip melalui lima tahap kegiatan pokok, yaitu mengamati (observing), menanya (questioning), melakukan/ mencoba (experimenting), menghubungkan/ mengasosiasi (asociating), dan mengkomunikasikan (communicating). Tahapan-tahapan tersebut merupakan bagian dari kegiatan ilmiah yang harus dilakukan dalam upaya mencari jawaban atas masalah atau 
menemukan kebenaran sebagaimana dituangkan dalam Permendikbud Nomor 81A/2013.

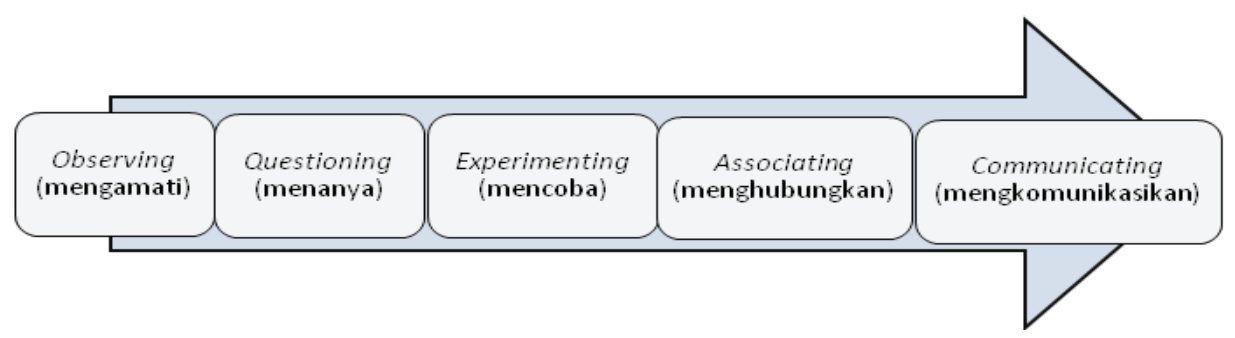

Penilaian Otentik (authentic assessment)

Menurut Jon Mueller penilaian otentik adalah bentuk penilaian yang meminta para siswanya untuk menampilkan tugas pada situasi yang sesungguhnya, mendemonstrasikan penerapan keterampilan dan pengetahuan esensial yang bermakna. Grant Wiggins (dalam Nuryani, tt:2), menekankan perlunya kinerja ditampilkan secara efektif dan kreatif, tugas yang diberikan dapat berupa pengulangan tugas atau masalah yang serupa dengan masalah yang dihadapi orang dewasa, baik sebagai warganegara, konsumen, atau professional di bidangnya. "...engaging and worthy problems or questions of importance, in which students must use knowledge to fashion performance effectively and creatively. The tasks are either replic as of or analogous to the kinds of problems faced by adult citizens and consumers or professionals in the field".

Penilaian otentik memiliki relevansi kuat terhadap pendekatan ilmiah dalam pembelajaran sesuai dengan tuntutan Kurikulum 2013. Penilaian tersebut mampu menggambarkan peningkatan hasil belajar peserta didik, baik dalam rangka mengobservasi, menalar, mencoba, membangun jejaring, dan lain-lain. Penilaian otentik cenderung fokus pada tugas-tugas kompleks atau kontekstual, yang memungkinkan peserta didik mampu menunjukkan kompetensi mereka dalam pengaturan yang lebih otentik.

Ada beberapa penelitian yang telah dilakukan terkait dengan tema pembelajaran integratif, di antaranya; Penelitian yang dilakukan oleh Suparni (2013) dari Universitas Negeri Yogyakarta (UNY) tentang Pengembangan Kemampuan Berpikir Kritis 
Mahasiswa Program Studi Matematika melalui pendekatan Integrasi Interkoneksi menyimpulkan bahwa pembelajaran matematika dengan pendekatan integrasi interkoneksi dapat mengembangkan kemampuan berpikir kritis mahasiswa program studi Matematika Fakultas Sain dan Teknologi UIN Sunan Kalijaga Yogyakarta. Hal ini dapat dilihat dari hasil analisis data skor rata-rata TKBK pada saat pratindakan sebesar 23, siklus I sebesar 27,7 dan siklus 3 sebesar 36,6 .

Penelitian pengembangan yang dilakukan oleh Slamet Fauzi (2012) dari UIN Sunan Kalijaga Yogyakarta tentang pengembangan buku ajar berbasis integrasi interkoneksi sebagai bahan pembelajaran fisika SMA/MA Kelas XI Semester I, menghasilkan buku ajar yang dinilai baik oleh ahli materi (skor 83), dinilai baik oleh ahli media pembelajaran (skor87), dinilai sangat baik oleh para guru SMA (skor 92,5), dinilai sangat baik oleh peer review (skor 90,2); berdasarkan uji coba terbatas tergolong sangat baik (skor 73), berdasarkan uji lapangan memiliki kualitas baik (skor 71,5).

Mencermati beberapa hasil penelitian tersebut, kajian yang mengembangkan integrasi interkoneksi yang diaplikasikan dalam pembelajaran tematik integratif baik internal maupun eksternal di Madrasah Ibtidaiyah belum dilakukan.

\section{Metode Penelitian}

Penelitian ini menggunakan pendekatan kualitatif jenis Research and Development (R\&D), yaitu jenis riset yang dilakukan dengan mengembangkan model yang sudah ada untuk menghasil model baru yang dianggap lebih efektif (Gall, 2003:569). Adapun tahapan kerja dalam R\&D ini mengikuti model yang dikembangkan oleh Dick \& Lau Cerey (Gall, 2003:571) yang terdiri dari sepuluh langkah sebagaimana bagan berikut. 


\section{The steps of the Systems Approach Model of Educational Research and Development (R\&D)}

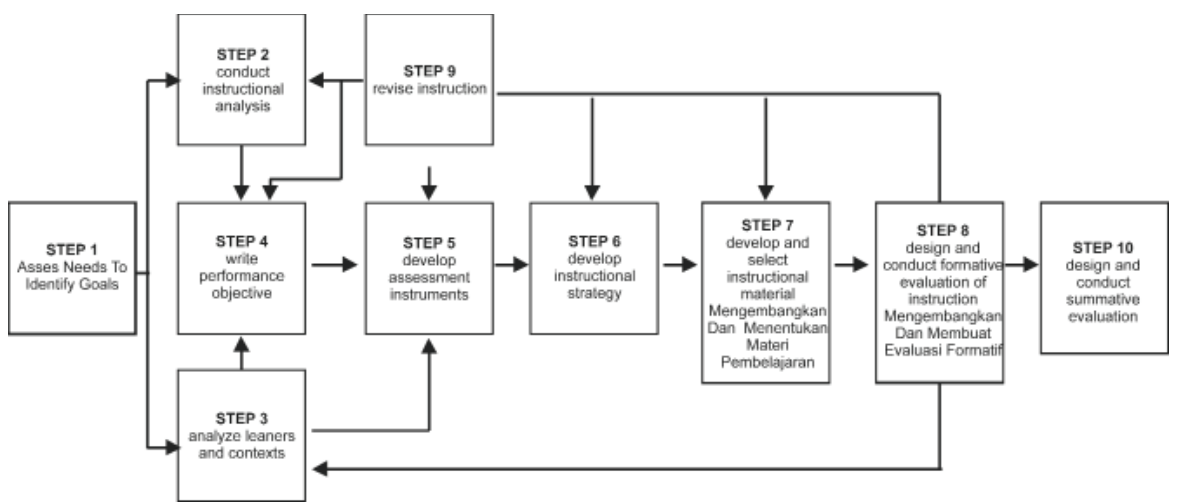

Sebelum melakukan uji coba pembelajaran di kelas, terlebih dahulu dilakukan pemetaan dan pembuatan jaringan tema pembelajaran integratif internal dan eksternal di Madrasah Ibtidaiyah dengan mengacu pada Permendikbud Nomor 67 Tahun 2013 tentang Kurikulum SD/MI, Permenag Nomor 8 Tahun 2008 tentang Standar Isi Madrasah Ibtidaiyah dan draft Permenag Tahun 2013 tentang Kurikulum 2013 Mata Pelajaran Pendidikan Agama Islam dan Bahasa Arab di Madrasah, Buku Pegangan Guru SD Kelas IV dan Buku Pegangan Guru PAI SD Kelas IV.

Penelitian ini dilaksanakan pada bulan November 2014. Dalam penelitian ini yang dijadikan subjek uji coba adalah siswa kelas IV MI Mangunsari Kota Salatiga Jawa Tengah karena siswa Kelas IV adalah salah satu tingkatan kelas di SD/MI yang dijadikan pilot project implementasi Kurikulum 2013. Indikator keberhasilan uji coba ini adalah: 1) Prestasi Belajar: mencapai KKM yang ditetapkan MI, yaitu 65; 2) Performa belajar peserta didik: performa peserta didik mencapai kategori baik

Teknikpengumpulandatadilakukanmelaluistudidokumentasi, tes, dan observasi. Data yang bersifat kuantitatif dianalisis dengan menggunakan statistik deskriptif, persentase; sedangkan data yang bersifat kualitatif dianalisis dengan menggunakan teknik analisis interaktif Miles \& Huberman (1994:10) yang terdiri dari data reduction, data display, conclusion and verification. 


\section{Analisis}

\section{Tematik Integratif Eksternal}

Setelah dilakukan pemetaan Kompetensi Dasar dan Indikator kemudian disambungkan dengan Tema-tema Pembelajaran yang sudah ada, maka indikator pembelajaran dalam sub-sub mapel Pendidikan Agama Islam yang terdiri dari Aqidah Akhlaq, Al Qur'an, Fiqh, dan Sejarah Kebudayaan Islam dapat masuk ke dalam 16 (enam belas) pembelajaran pada semester I Kelas IV dan 24 (dua puluh empat) pembelajaran pada Semester II Kelas IV.

Penyebaran tema masing-masing semester tidak bisa sama karena Kompetensi Dasar yang ada pada sub mapel Pendidikan Agama Islam tidak bisa dilaksanakan masuk pada sebaran tema pembelajaran yang sudah ada pada mata pelajaran umum (IPA, PPKn, IPS, PJOK, SBdB, Matematika, Bahasa Indonesia). Kalau dilaksanakan justru akan semakin tidak koheren antara Kompetensi Dasar yang ada dengan tema pembelajaran yang bersangkutan.

Adapun penyebaran Kompetensi Dasar sub_able Pendidikan Agama Islam dalam mata pelajaran umum di Madrasah Ibtidaiyah dapat dilihat pada rangkuman taable berikut.

Tabel 1

Penyebaran Jaringan Tematik Integratif Eksternal

\begin{tabular}{cccccc}
\hline & \multicolumn{2}{c}{ Semester Ganjil } & \multicolumn{3}{c}{ Semester Genap } \\
\hline Tema & $\begin{array}{c}\text { Sub } \\
\text { Tema }\end{array}$ & Pembelajaan & Tema & $\begin{array}{c}\text { Sub } \\
\text { Tema }\end{array}$ & Pembelajaan \\
\hline 1 & 1 & 1 & 5 & 1 & 1 \\
& & 3 & & & 3 \\
& & 4 & & & 5 \\
& 2 & 2 & & 2 & 1 \\
& & 4 & & & 4 \\
3 & 3 & 6 & & 3 & 5 \\
& 1 & 1 & & & 2
\end{tabular}




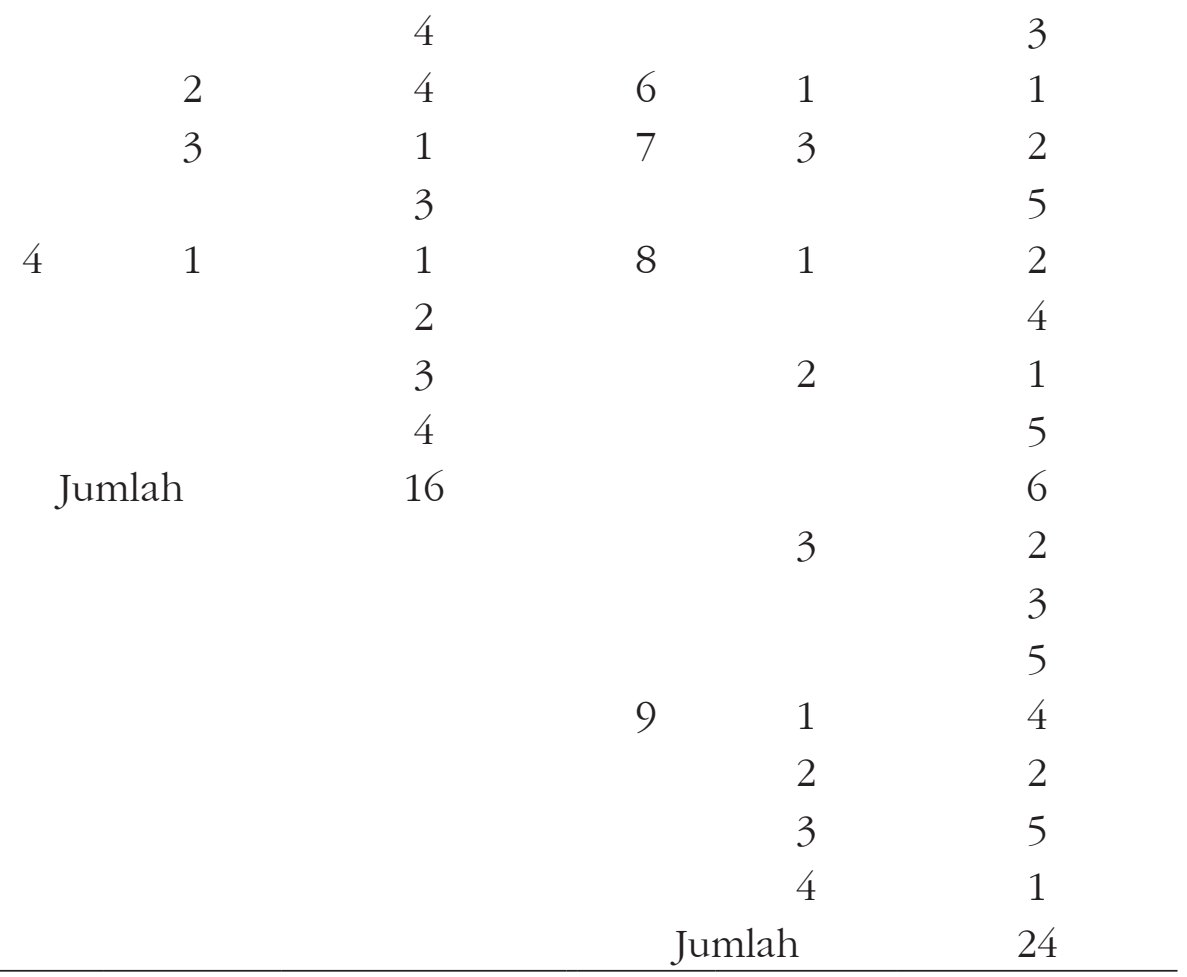

Rincian penyebaran masing-masing tema pada masingmasing pertemuan perminggu dapat dilihat pada tabel di bawah ini. 


\section{Tabel 2}

\begin{tabular}{|c|c|c|c|c|c|c|c|c|c|c|c|c|c|c|c|c|c|c|c|c|c|c|c|c|c|c|}
\hline \multicolumn{27}{|c|}{ TEMA 1} \\
\hline \multicolumn{6}{|c|}{ Sub Tema 1} & \multirow{2}{*}{$\begin{array}{l}\mathrm{J} \\
\mathrm{a} \\
\mathrm{m}\end{array}$} & \multicolumn{6}{|c|}{ Sub Tema 2} & $\mathrm{~J}$ & \multicolumn{6}{|c|}{ Sub Tema 3} & \multirow{2}{*}{$\begin{array}{l}\mathrm{J} \\
\mathrm{a} \\
\mathrm{m}\end{array}$} & \multicolumn{6}{|c|}{ Sub Tema 4} \\
\hline 1 & 2 & 3 & 4 & 5 & 6 & & 1 & 2 & 3 & 4 & 5 & 6 & $\begin{array}{l}\mathrm{a} \\
\mathrm{m}\end{array}$ & 1 & 2 & 3 & 4 & 5 & 6 & & 1 & 2 & 3 & 4 & 5 & 6 \\
\hline & $\mathrm{P}$ & & & $\mathrm{P}$ & $P$ & 1 & $\mathrm{P}$ & & $P$ & & $P$ & $P$ & 1 & \multicolumn{6}{|c|}{ Pembiasaan Akhlaq } & 1 & \multicolumn{6}{|c|}{ Pembiasaan Hafalan } \\
\hline & & & & & & 2 & & & & & & & 2 & & & & & & & 2 & & & & & & \\
\hline & & & & & & 3 & & & & & & & 3 & & & & & & & 3 & & & & & & \\
\hline & & & & & & 4 & & & & & & & 4 & & & & & & & 4 & & & & & & \\
\hline & & & & & & 5 & & & & & & & 5 & & & & & & & 5 & & & & & & \\
\hline & & & & & & 6 & & & & & & & 6 & & & & & & & 6 & & & & & & \\
\hline & & & & & & 7 & & & & & & & 7 & & & & & & & 7 & & & & & & \\
\hline
\end{tabular}

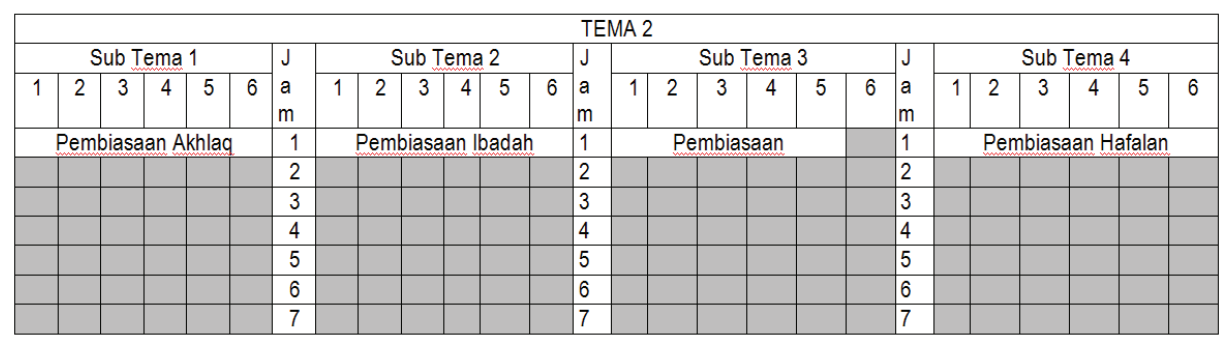

\begin{tabular}{|c|c|c|c|c|c|c|c|c|c|c|c|c|c|c|c|c|c|c|c|c|c|c|c|c|c|c|}
\hline \multicolumn{27}{|c|}{ TEMA 3} \\
\hline \multicolumn{6}{|c|}{ Sub Tema 1} & \multirow{2}{*}{$\begin{array}{l}\mathrm{J} \\
\mathrm{a} \\
\mathrm{m}\end{array}$} & \multicolumn{6}{|c|}{ Sub Tema 2} & $\mathrm{~J}$ & \multicolumn{6}{|c|}{ Sub Tema 3} & \multirow{2}{*}{$\begin{array}{l}\mathrm{J} \\
\mathrm{a} \\
\mathrm{m}\end{array}$} & \multicolumn{6}{|c|}{ Sub Tema 4} \\
\hline 1 & 2 & 3 & 4 & 5 & 6 & & 1 & 2 & 3 & 4 & 5 & 6 & $\begin{array}{l}a \\
m\end{array}$ & 1 & 2 & 3 & 4 & 5 & 6 & & 1 & 2 & 3 & 4 & 5 & 6 \\
\hline & $P$ & & & $P$ & $P$ & 1 & $P$ & $P$ & $P$ & & $P$ & $P$ & 1 & & $P$ & & $P$ & $P$ & $P$ & 1 & & & bias & an & adah & \\
\hline & & & & & & 2 & & & & & & & 2 & & & & & & & 2 & & & & & & \\
\hline & & & & & & 3 & & & & & & & 3 & & & & & & & 3 & & & & & & \\
\hline & & & & & & 4 & & & & & & & 4 & & & & & & & 4 & & & & & & \\
\hline & & & & & & 5 & & & & & & & 5 & & & & & & & 5 & & & & & & \\
\hline & & & & & & 6 & & & & & & & 6 & & & & & & & 6 & & & & & & \\
\hline & & & & & & 7 & & & & & & & 7 & & & & & & & 7 & & & & & & \\
\hline
\end{tabular}

\begin{tabular}{|c|c|c|c|c|c|c|c|c|c|c|c|c|c|c|c|c|c|c|c|c|c|c|c|c|c|c|}
\hline \multicolumn{27}{|c|}{ TEMA 4} \\
\hline \multicolumn{6}{|c|}{ Sub Tema 1} & $\mathrm{~J}$ & \multicolumn{6}{|c|}{ Sub Tema 2} & $\mathrm{~J}$ & \multicolumn{6}{|c|}{ Sub Tema 3} & $\mathrm{~J}$ & \multicolumn{6}{|c|}{ Sub Tema 4} \\
\hline 1 & 2 & 3 & 4 & 5 & 6 & $\begin{array}{l}a \\
m\end{array}$ & 1 & 2 & 3 & 4 & 5 & 6 & a & 1 & 2 & 3 & 4 & 5 & 6 & a & 1 & 2 & 3 & 4 & 5 & 6 \\
\hline & & & & $P$ & $P$ & 1 & & Pem & ias: & an It & adah & & 1 & & & bias & an $A$ & hlag & & 1 & & Pem & ias & $\mathrm{n} F$ & fala & \\
\hline & & & & & & 2 & & & & & & & 2 & & & & & & & 2 & & & & & & \\
\hline & & & & & & 3 & & & & & & & 3 & & & & & & & 3 & & & & & & \\
\hline & & & & & & 4 & & & & & & & 4 & & & & & & & 4 & & & & & & \\
\hline & & & & & & 5 & & & & & & & 5 & & & & & & & 5 & & & & & & \\
\hline & & & & & & 6 & & & & & & & 6 & & & & & & & 6 & & & & & & \\
\hline & & & & & & 7 & & & & & & & 7 & & & & & & & 7 & & & & & & \\
\hline
\end{tabular}

\begin{tabular}{|c|c|c|c|c|c|c|c|c|c|c|c|c|c|c|c|c|c|c|c|c|c|c|c|c|c|c|}
\hline \multicolumn{27}{|c|}{ TEMA 5} \\
\hline \multicolumn{6}{|c|}{ Sub Tema 1} & \multirow{2}{*}{$\begin{array}{l}\mathrm{J} \\
\mathrm{a} \\
\mathrm{m}\end{array}$} & \multicolumn{6}{|c|}{ Sub Tema 2} & \begin{tabular}{|l|l}
$\mathrm{J}$ \\
\end{tabular} & \multicolumn{6}{|c|}{ Sub Tema 3} & \multirow{2}{*}{$\begin{array}{l}\mathrm{J} \\
\mathrm{a} \\
\mathrm{m}\end{array}$} & \multicolumn{6}{|c|}{ Sub Tema 4} \\
\hline 1 & 2 & 3 & 4 & 5 & 6 & & 1 & 2 & 3 & 4 & 5 & 6 & $\begin{array}{l}\mathrm{a} \\
\mathrm{m}\end{array}$ & 1 & 2 & 3 & 4 & 5 & 6 & & 1 & 2 & 3 & 4 & 5 & 6 \\
\hline & $P$ & & $P$ & & $P$ & 1 & & $P$ & $P$ & & & $P$ & 1 & & & & $P$ & $P$ & $P$ & 1 & & & ias & an $A$ & hlag & \\
\hline & & & & & & 2 & & & & & & & 2 & & & & & & & 2 & & & & & & \\
\hline & & & & & & 3 & & & & & & & 3 & & & & & & & 3 & & & & & & \\
\hline & & & & & & 4 & & & & & & & 4 & & & & & & & 4 & & & & & & \\
\hline & & & & & & 5 & & & & & & & 5 & & & & & & & 5 & & & & & & \\
\hline & & & & & & 6 & & & & & & & 6 & & & & & & & 6 & & & & & & \\
\hline & & & & & & 7 & & & & & & & 7 & & & & & & & 7 & & & & & & \\
\hline
\end{tabular}


Keterangan :

Pembelajaran tematik integratif eksternal dilaksanakan sampai jam ke-7.

$\mathrm{P}=$ pembiasaan

Dari paparan tabel di atas, dapat dipahami bahwa tema pembelajaran Pendidikan Agama Islam di Madrasah Ibtidaiyah tidak bisa masuk secara runtut, urut setiap hari pada tema pembelajaran tematik yang lainnya.

Jika model ini dipandang cocok untuk dikembangkan di Madrasah Ibtidaiyah, maka yang dilakukan adalah memanfaatkan waktu jam-jam "kosong" tersebut untuk kegiatan pembiasaan ibadah, akhlaq karimah dan hafalan ayat atau do'a pilihan. Pembiasaan yang dimaksud misalnya pembiasaan kebersihan, ketertiban, dan disiplin; hafalan asma' al-busna, hafalan surat-surat pendek, hafalan hadits-hadits pilihan, sholat dhuha bersama, tadarrus bersama, dan kegiatan keagamaan yang lainnya.

Kegiatan-kegiatan tersebut tentunya tidak dapat dilaksanakan setiap hari, namun dilaksanakan secara terjadwal, bergantian. Keuntungan yang dapat diperoleh dari model demikian adalah peserta didik mendapatkan pendidikan praktis dalam hal keberagamaan, tidak hanya pengetahuan semata.

Adapun contoh pemetaan jaringan tematik integratif eksternal dapat dilihat pada bagan-bagan di bawah ini.

Tema 1 : Indahnya Kebersamaan

Subtema 1 : Keragaman Budaya Bangsaku

Pembelajaran 1 


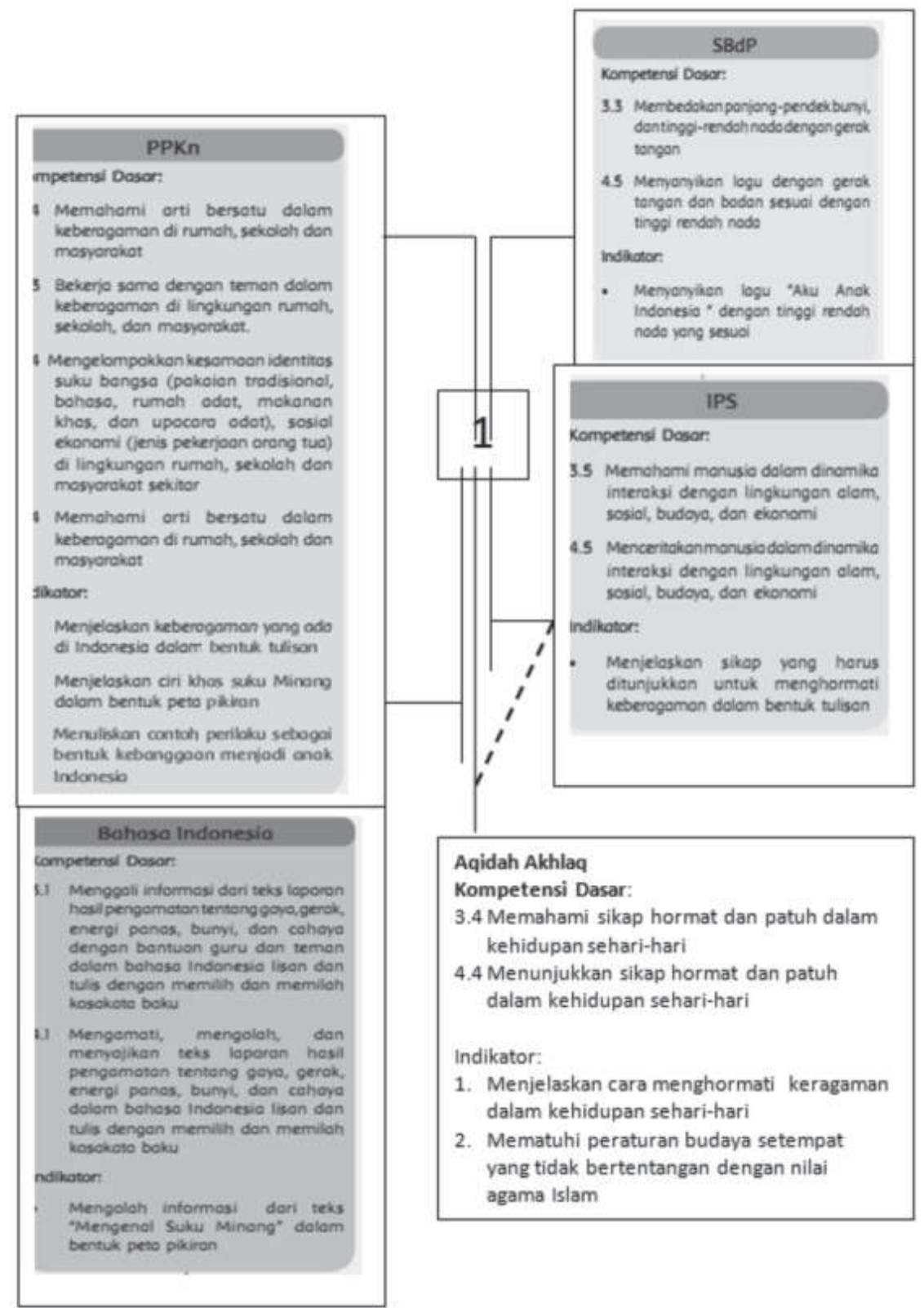

\section{Gambar 1}

\section{Pemetaan Jaringan Tematik Integratif Eksternal}


Pada bagan di atas, dapat dilihat bahwa sub mapel Aqidah Akhlaq diintegrsikan dengan tema Indahnya Kebersamaan sub tema Keragaman Budaya Bangsaku yang terdiri dari mapel PPKn, SBdP, dan Bahasa Indonesia. Dalam praktik pembelajarannya, materi Aqidah Akhlaq masuk melalui mapel IPS, indikator: menjelaskan sikap yang harus ditunjukkan untuk menghormati keberagaman dalam bentuk lisan.Ketika guru menerangkan IPS tentang sikap menghormati keberagaman, maka guru dapat menyambungkan dengan indikator dalam Aqidah Akhlaq, yaitu: 1) menjelaskan cara menghormati keragaman dalam kehidupan sehari-hari; 2) mematuhi peraturan budaya setempat yang tidak bertentangan dengan nilai agama Islam.

\section{Tematik Integratif Internal di Madrasah}

Dimaksudkan dengan pengembangan model pembelajaran tematik integratif internal adalah pembelajaran tematik yang dilakukan dengan mencari keterkaitan antar kompetensi dasar dari berbagai sub mapel agama (Aqidah Akhlaq, Fiqh, al Qur'an Hadits dan Sejarah Kebudayaan Islam) dan diikat dalam satu tema pembelajaran.

Dalam pembelajaran agama Islam di Madrasah Ibtidaiyah yang terdiri dari sub-sub mata pelajaran, beberapa kompetensi dasar yang ada dari berbagai sub mapel ternyata sulit untuk dicari titik temu dalam satu tema pembelajaran. Kesulitan dalam mencari titik temu tema ini karena masing-masing sub mata pelajaran memiliki squance sendiri-sendiri yang tidak terkait dengan squance sub mata pelajaran yang lainnya, sehingga masing-masing harus berjalan sesuai dengan urutan masing-masing. Kalau dipertemukan dalam satu tema pembelajaran, justru satu sub mata pelajaran harus meloncat dari squance-nya/runtutannya, mengurangi kedalaman materi, jam pembelajaran, dan tidak berbeda dengan pembelajaran agama di SD.

Adapun tema-tema dan urutan pembelajaran agama Islam di Madrasah Ibtidaiyah dapat dilihat dalam tabel berikut. 
Tabel 3

Pemetaan KD Mapel Pendidikan Agama Islam di Madrasah Ibtidaiyah

Semester Gasal

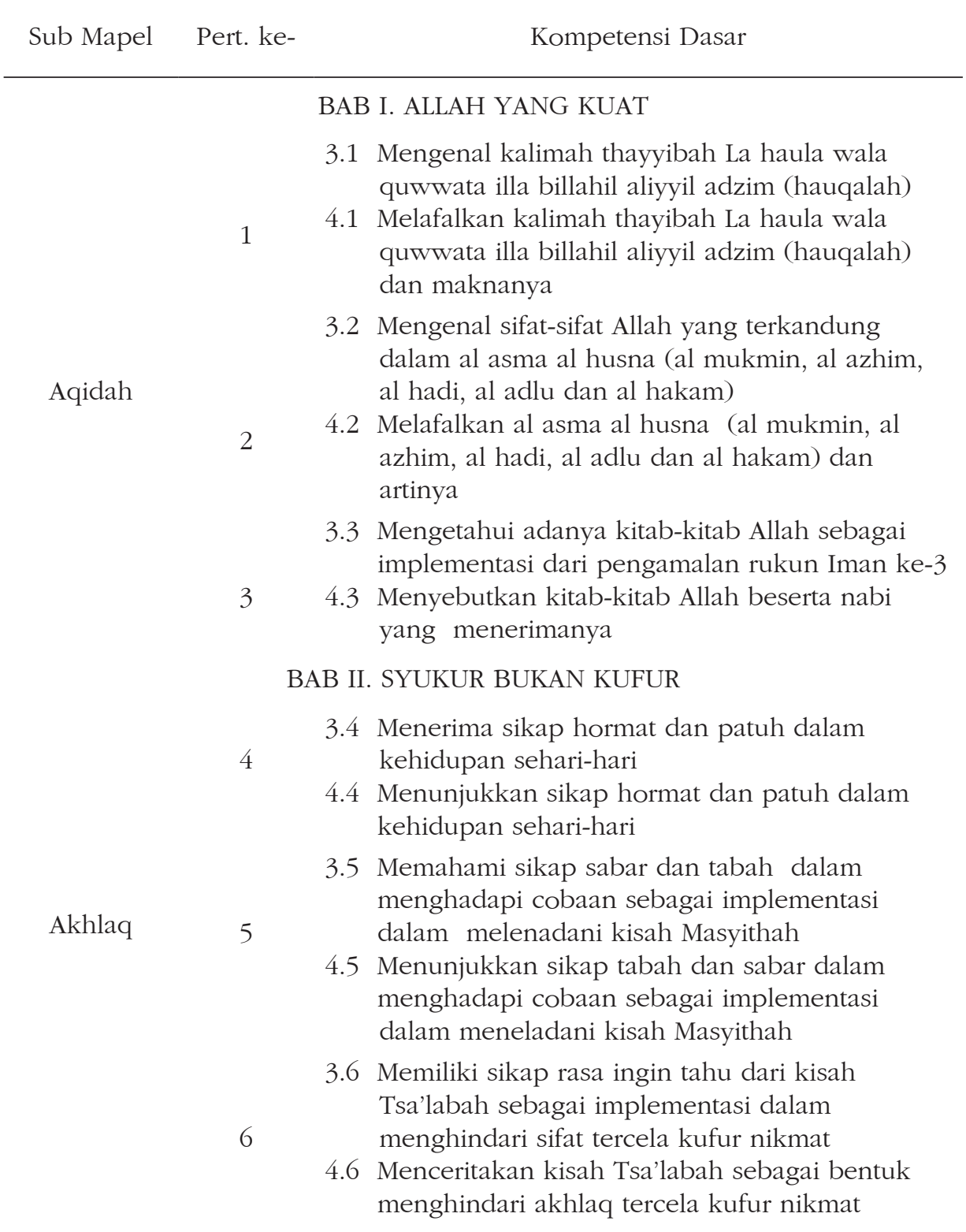




\section{BAB III. IHLAS BERAMAL}

$7 \quad 3.1$ Menerjemahkan surat al Nashr, al Kautsar dan al Adiyat sehari-hari

$8 \quad 3.2$ Memahami isi kandungan surat al Nashr dan al Kautsar

Al Qur'an

$9 \quad 3.3$ Memahami hukum bacaan idhar dan ikhfa'

4.3 Menerapkan hukum bacaan idhar dan ikhfa'

3.4 Menerjemahkan hadits tentang niat riwayat Bukhari dari Umar bin Khattab

3.5 Memahami isi kandungan hadits tentang niat riwayat Bukhari dari Umar bin Khattab

4.4 Menghafalkan hadits tentang niat riwayat Bukhari dari Umar bin Khattab

3.6 Menerjemahkan hadits tentang taqwa riwayat

11 Tirmidzi dari Abu Dzar

3.7 Memahami isi kandungan hadits tentang taqwa riwayat Tirmidzi dari Abu Dzar

124.5 Menghafalkan hadits tentang taqwa riwayat Tirmidzi dari Abu Dzar

\section{BAB IV. MARI BERBAGI}

$13 \quad 3.1$ Memahami pengertian zakat, infaq, dan sedekah 3.2 Mengenal macam-macam zakat

Fiqh

$14 \quad 3.3$ Memahami ketentuan zakat fithrah

153.4 Memahami ketentuan infaq dan sedekah

4.2 Mensimulasikan tata cara infaq dan sedekah

163.5 Mengetahui manfaat zakat, infaq dan sedekah BAB V. BERJIHAD

3.1 Mengetahui contoh-contoh ketabahan nabi Muhammad SAW dan para sahabat dalam berdakwah

SKI

4.1 Menceritakan ketabahan nabi Muhammad SAW dan sahabat dalam berdakwah

3.2 Memahami ciri-ciri kepribadian nabi Muhammad SAW sebagai rahmat bagi seluruh alam

4.2 Menceritakan kemuliaan akhlaq nabi Muhammad SAW dan sahabat dalam berdakwah 


\section{Tabel 4}

\section{Pemetaan KD Mapel Pendidikan Agama Islam di Madrasah Ibtidaiyah \\ Semester Genap}

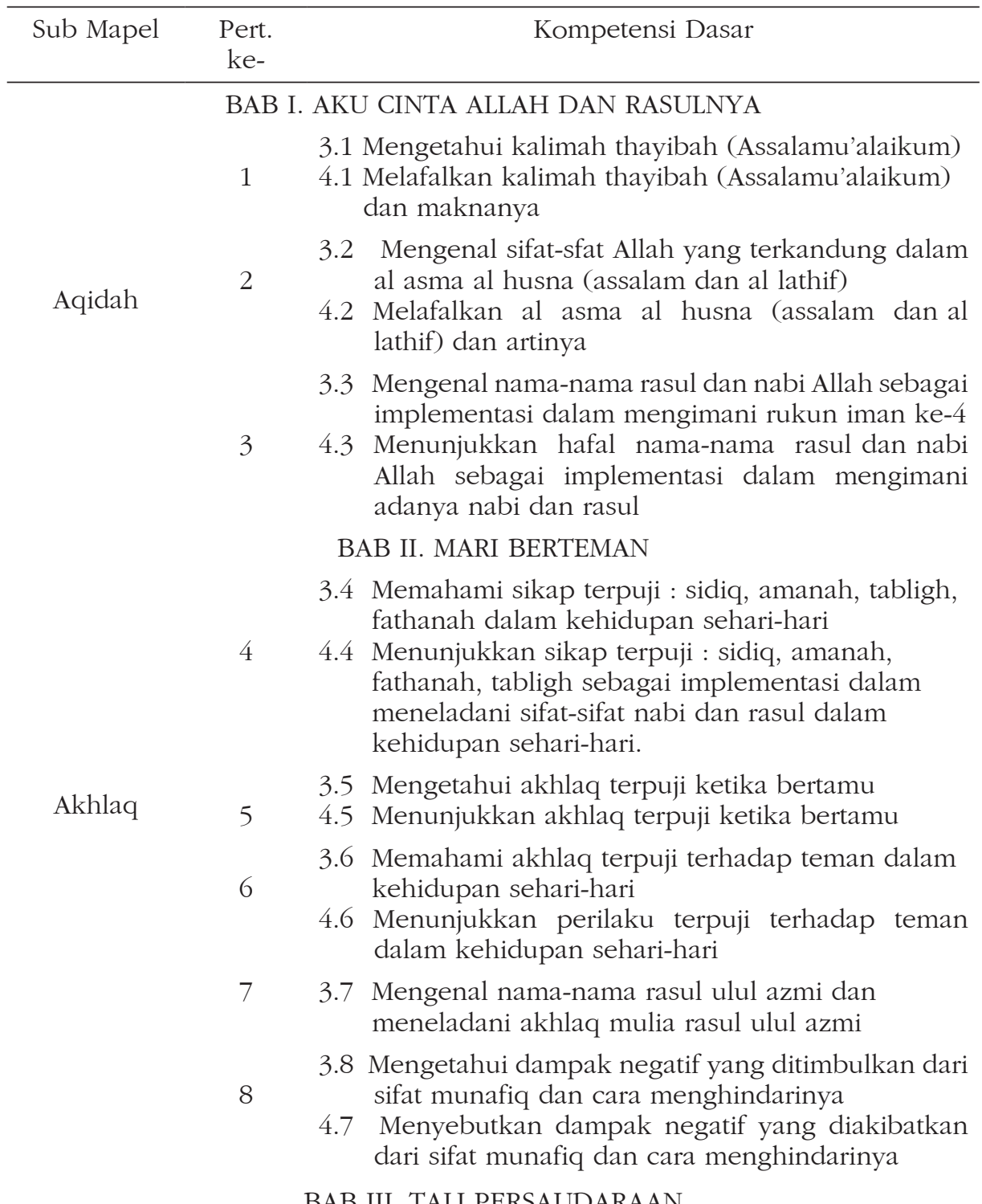

BAB III. TALI PERSAUDARAAN 
$9 \quad 3.1$ Menerjemahkan surat al Lahab

3.2 Memahami isi kandungan surat al Lahab

$10 \quad 4.1$ Membaca surat al Insyirah

4.2 Menghafalkan surat al Insyirah secara fasih dan benar

Al Qur'an

113.4 Memahami isi kandungan hadits tentang silaturrahim riwayat Bukhari Muslim dari Anas

4.3 Menghafalkan hadits tentang silaturrahim riwayat Bukhari Muslim dari Anas

124.4 Menerapkan hukum bacaan idgham bighunnah, idgham bila ghunnah dan iqlab

\section{BAB IV. BAHAGIA DI HARI RAYA}

$13 \quad 3.1$ Memahami pengertian sholat Id

3.2 Mengenal macam-macam sholat Id

$14 \quad 3.3$ Memahami ketentuan sholat Id

Fiqh

4.1 Mendemonstrasikan tata cara sholat Id

153.4 Memahami ketentuan sholat Jumat

4.2 Mensimulasikan tata cara sholat Jumat

163.5 Mengenali perbedaan ketentuan sholat Id dan sholat Jumat

3.6 Mengetahui hikmah sholat Jumat dan sholat Id

BAB V. BERHIJRAH? SIAPA TAKUT..!

3.1 Mengetahui sebab-sebab nabi Muhammad SAW menganjurkan sahabat hijrah ke Habsyah

4.1 Menceritakan peristiwa hijrah ke Habsyah

3.2 Mengetahui sebab-sebab nabi Muhammad SAW hijrah ke Thaif

4.2 Menceritakan peristiwa hijrah sahabat ke Thaif

SKI

3.3 Mengenal latar belakang nabi Muhammad di Isra'Mi'raj kan Allah SWT

4.3 Menceritakan kembali peristiwa penting dalam Isra Mi'raj nabi Muhammad SAW

203.4 Memahami keadaan masyarakat Yatsrib sebelum hijrah nabi Muhammad SAW

3.5 Mengetahui sebab-sebab nabi Hijrah ke Yatsrib

4.4 Menceritakan kembali peristiwa hijrah nabi Muhammad ke Yatsrib

213.6 Mengenal upaya yang dilakukan nabi Muhammad dalam membina masyarakat Madinah (sosial, ekonomi, agama dan pertahanan) 
Mencermati paparan tabel di atas, maka pembelajaran agama Islam di Madrasah Ibtidaiyah lebih efektif berdiri sendiri dengan sub-sub mapel yang ada, hal ini berarti gagasan pembelajaran tematik integratif internal sepertinya masih sulit diwujudkan, baik pada dataran konseptual maupun praktik di lapangan. Jika penyebaran tema-tema dan KD di atas disepakati, maka yang terjadi justru akan mendangkalkan pembelajaran agama Islam itu sendiri, karena pendidikan agama hanya diberikan dua jam pelajaran dalam seminggu.

Namun di sisi lain, jika model pemetaan di atas disepakati maka pembelajaran agama di Madrasah Ibtidaiyah memiliki banyak waktu untuk melakukan praktik dan pembiasaan untuk mengembangkan aspek afektif dan psikomotorik. Setiap minggu berarti ada 2 x 5 jam pelajaran pendidikan agama Islam di Madrasah Ibtidaiyah yang dapat digunakan para guru untuk membentuk peserta didik menjadi anak sholih yang terampil beribadah. adalah:

Selama ini jadwal pembelajaran di Madrasah Ibtidaiyah 07.00 - 08.00 : Ikrar, do'a, Sholat Dhuha, Hafalan Surat Pendek 08.00 - 13.15 : Kegiatan Belajar Mengajar (Senin - Rabu) $08.00-12.15$ : Kegiatan Belajar Menajar (Kamis) 12.15 - 13.15 : Ekstrakurikuler Pramuka (Kamis) $08.00-10.45$ : Kegiatan Belajar Mengajar (Jum'at) $08.00-10.00$ : Kegiatan Belajar Mengajar (Sabtu)

Jika pembelajaran tematik integratif eksternal dan internal model ini dikembangkan, maka penjadwalannya akan berubah di mana pembelajaran dapat dimulai jam 07.00-13.15; sementara kegiatan ikrar, do'a, sholat dhuha, dan hafalan surat pendek dapat dilaksanakan pada hari-hari pembelajaran tematik biasa. Hal ini sangat menguntungkan bagi sekolah, karena pembelajaran dapat dilaksanakan sesuai dengan standar waktu yang ditetapkan oleh Kementerian. Selama ini pembelajaran tematik di Madrasah Ibtidaiyah terkurangi oleh jam pertama untuk kegiatan penguatan aspek keagamaan peserta didik. 


\section{Hasil Uji Coba di lapangan}

Pembelajaran tematik integratif internal telah dilakukan uji coba terbatas pada hari Rabu tanggal 26 Nopember 2014 di kelas IV Madrasah Ibtidaiyah Mangunsari Kota Salatiga Jawa Tengah. Dalam uji coba di lapangan, guru melaksanakan kegiatan pembelajaran sesuai dengan skenario yang tertulis di dalam Rencana Pelaksanaan Pembelajaran, mulai kegiatan pembukaan, inti, dan kegiatan penutup. Kegiatan berjalan lancar sesuai dengan yang direncanakan.

Selama kegiatan pembelajaran berlangsung, peserta didik dapat mengikuti kegiatan pembelajaran sebagaimana mestinya, mereka terlihat antusias, aktif mengikuti pembelajaran dan mengikuti skenario pembelajaran yang telah direncanakan oleh guru. Peserta didik terlihat capek dan boring saat memasuki sesi menceritakan peristiwa Isra' Mi'raj. Mereka belum memiliki kemampuan mengembangkan cerita sehingga merasa kesulitan. Rasa boring peserta didik terlihat mulai hilang ketika pembahasan mulai masuk pada sub mata pelajaran Matematika, Kompetensi Dasar memahami aturan pembulatan dalam membaca hasil pengukuran dengan alat ukur. Pada sesi ini peserta didik diajak melakukan kegiatan yaitu menimbang benda-benda dengan alat timbangan. Mereka tidak mengantuk lagi, di samping itu sebelum masuk pada sub mapel Matematika, guru mengajak peserta didik menyanyi lagu: Sholat secara bersama-sama. Lagu Sholat dinyanyikan terkait dengan peristiwa Isra' Mi'raj, di mana hasil perjalanan tersebut Rasul menerima perintah untuk melaksanakan sholat lima waktu.

Menurut Kn dan An (wawancara tanggal 28 Nopember 2014), guru kelas IV yang melaksanakan pembelajaran tematik integratif eksternal, pembelajaran model begitu dirasa enak dan nyaman karena guru tidak harus berpindah pada sub mapel tersendiri, yaitu Pendidikan Agama Islam. Pembelajaran bisa terus berlangsung dengan tidak perlu ada perpindahan jam mata pelajaran.

\section{Kesimpulan}

Setelah melakukan kajian dan uji coba terbatas pembelajaran tematik integratif internal dan eksternal di Madrasah Ibtidaiyah, dapat disimpulkan bahwa penyebaran KD pada sub-sub mata 
pelajaran Pendidikan Agama Islam di Madrasah Ibtidaiyah tidak dapat masuk pada setiap tema pembelajaran yang telah disusun oleh Kementerian Pendidikan Nasional. Squance bahasan pada mata pelajaran Pendidikan Agama Islam di Madrasah Ibtidaiyah berbeda dengan squance yang ada pada mata pelajaran lain yang tercakup dalam tema-tema pembelajaran mata pelajaran lainnya. Pada semester ganjil kelas IV, KD mapel PAI dapat diintegrasikan ke dalam 16 kali pertemuan, sedangkan pada semester genap KD mapel PAI dapat diintegrasikan ke dalam 24 kali pertemuan secara tidak berurutan.

Untuk pembuatan jaringan tematik integratif internal di Madrasah Ibtidaiyah dapat dilakukan dengan membuat tema pembelajaran dalam lingkup sub mata pelajaran PAI. Penyusunan jaringan tema integratif internal masih sulit dilakukan karena masing-masing sub mapel PAI memiliki hirarchis pembahasan keilmuan yang berbeda dengan sub mapel PAI lainnya, sehingga kalau dipaksakan justru tidak berkaitan. Pada semester gasal Kelas IV, pembelajaran PAI di Madrasah dapat dijabarkan ke dalam 18 kali pertemuan, sedangkan semester genap dapat dijabarkan ke dalam 21 kali pertemuan.

Setelah dilakukan uji coba terbatas, Kn dan An (guru kelas IV MI Mangunsari Kota Salatiga) menyatakan bahwa dia merasa nyaman dan cocok mengajar dengan model tersebut karena tidak harus melakukan pergantian jam pelajaran dari tema biasa ke pembelajaran PAI. Peserta didik juga terlihat senang mengikuti pembelajaran tersebut, sedangkan dilihat dari hasil evaluasinya menunjukkan hasil yang baik.

\section{Daftar Pustaka}

Depdikbud. 2013. Tema 1 Diriku Buku Tematik Terpadu Kurikulum 2013. Jakarta: Depdikbud

Draft Permenag Tahun 2013 tentang Kurikulum 2013 Mata Pelajaran Pendidikan Agama Islam dan Bahasa Arab di Madrasah 
Fandy Saputra. 2013. Pengertian Integrasi Inerkoneksi diakses dari http://isic-suka.blogspot.com/2013/01/pengertian-integrasiinterkoneksi.html,tanggal 15 November 2015, pukul 06.30 WIB

Gall, Meredith D., \& Gall, Joyce P. 2003. Educational Research. Boston: Allyn Bacon

Jeanne Ellis Ormrod. 2011. Educational psychology: Developing Learners. Boston: Pearson Education, Inc.

Kementerian Pendidikan dan Kebudayaan. 2013. Pendidikan Agama Islam dan Budi Pekerti SD/MI Kelas IV. Jakarta: Kementerian Pendidikan dan Kebudayaan

Lampiran IV Permendikbud Nomor 81A tentang implementasi kurikulum 2013

Margaret E. Bell Gredler. 1991. Belajar dan Membelajarkan. Jakarta: Rajawali

Permendikbud Nomor 67 Tahun 2013 tentang Kurikulum SD/MI

Permenag Nomor 8 Tahun 2008 tentang Standar Isi Madrasah Ibtidaiyah

Usa (editor). 1991. Pendidikan Islam di Indonesia: Antara Cita dan Fakta. Jakarta

Trianto. 2010. Pembelajaran Tematik Integratif. Malang: UIN Malang Press

Nuryani Y. Rustaman. tt. Penilaian Otentik dan Penerapannya dalam pembelajaran sain diakses dari http://file.upi.edu/Direktori/ Sps/Prodi. Pendidikan _Ipa/ 195012311979032- Nuryani_ Rustaman/ Penilaian_Otentik_Sgr'06.Pdf, tanggal 10 Oktober 2015 pukul 10.20 WIB 
Yuswadiwijaya. 2013. Prinsip dasar pembelajaran tematik, diakses dari http://yuswadiwijaya.blogspot.com/2013/06/prinsipdasar-pembelajaran-tematik_9.html, tanggal 7 Oktober 2013 pukul 10.00 WIB. 